Jurnal Ekonomi dan Industri

Volume 20, No. 1, Januari-April 2019

p-ISSN : 0853-5248

\title{
PENGARUH TATA KELOLA PERUSAHAAN TERHADAP KINERJA KEUANGAN DAN KINERJA SAHAM PADA INDEKS SAHAM LQ45
}

\author{
Rachmaniar Myrianda Dwiputri*) \\ ${ }^{*}$ Dosen Program Studi Manajemen FE UNKRIS \\ Alamat: Kampus UNKRIS, Jatiwaringin Jakarta Timur \\ Email: rachmaniarmd@unkris.ac.id
}

\begin{abstract}
The aim of the company is to get a profit, so the company can be run properly as it should. The management of the company cannot necessarily do various ways to achieve this goal by itself, there are internal and external interests that will directly or indirectly affect the management. Companies are required to follow applicable rules to minimize conflicts of interest within the company. These rules are outlined in the Implementation of Corporate Governance. It is expected that with the implementation of Good Corporate Governance, it will improve the company's performance, especially the financial performance and performance of the company's shares. Therefore, this study aims to look at the influence of good corporate governance on financial performance and the performance of the company's shares. This research used a purposive sampling method in selecting samples and research samples are 45 companies indexed by LQ45 shares in the period of August 2016 - January 2017. Data used are secondary data and the variables used in this study are the financial ratios of DAR, DER, NPM, ROA, ROE, EPS, and PBV. In addition, the variables of Good Corporate Governance consist of Size of Commissioners, Independent Commissioners, Concentrated Ownership, and Proportion of Independent Commissioners. The relationship between variables of Corporate Governance, Financial Performance, and Stock Performance was tested using Structural Equation Modeling (SEM). The results found that Corporate Governance did not have a significant effect and positively related to the Financial Performance and Stock Performance of the LQ45 index company for the period of August 2016 - January 2017. While the Financial Performance significantly affected the direction of the positive relationship to Stock Performance
\end{abstract}

Keywords: Corporate governance, financial performance, performance shares, stock indices $L Q 45$

\section{PENDAHULUAN}

Tata Kelola Perusahaan atau Good Corporate Governance pertama kali diperkenalkan pada tahun 1998 di Indonesia. Cadbury (1992) mengemukakan bahwa Tata Kelola Perusahaan adalah suatu prinsip yang mengarahkan dan mengendalikan perusahaan agar mencapai keseimbangan antara kekuatan serta kewenangan perusahaan dalam memberikan pertanggungjawaban kepada para pemegang saham khususnya dan stakeholder pada umumnya. Menurut Warsono et al. (2009), Tata Kelola Perusahaan adalah suatu sistem yang terdiri dari fungsi-fungsi yang dijalankan oleh pihak-pihak yang berkepentingan dalam rangka memaksimalkan penciptaan nilai perusahaan sebagai entitas ekonomi maupun entitas sosial melalui penerapan prinsip-prinsip dasar yang diterima umum. Secara umum, prinsip Tata Kelola Perusahaan terdiri dari lima prinsip yaitu transparansi, akuntabilitas, pertanggungjawaban, kemandirian, serta keadilan dan kewajaran. Penerapan Tata Kelola Perusahaan diharapkan mampu meningkatkan nilai perusahaan. 
Nilai perusahaan merupakan kondisi yang telah dicapai oleh suatu perusahaan sebagai gambaran dari kepercayaan masyarakat terhadap perusahaan setelah melalui suatu proses kegiatan selama beberapa tahun, yaitu sejak perusahaan tersebut didirikan sampai dengan saat ini. Meningkatnya nilai perusahaan adalah sebuah prestasi, yang sesuai dengan keinginan para pemiliknya, karena dengan meningkatnya nilai perusahaan, maka kesejahteraan para pemilik juga akan meningkat. Nilai perusahaan dapat dilihat dari kinerja keuangan perusahaan dan kinerja saham. Kinerja keuangan perusahaan dapat diukur melalui beberapa rasio diantaranya rasio likuiditas, rasio leverage, rasio profitabilitas, rasio aktivitas dan rasio pasar. Pada penelitian ini rasio yang dianalisa adalah rasio leverage dan rasio profitabilitas. Rasio leverage mengukur kemampuan perusahaan dalam memenuhi kewajiban jangka panjangnya. Rasio leverage terdiri dari Debt to Assets Ratio dan Debt to Equity Ratio. Rasio profitabilitas bertujuan untuk mengetahui kemampuan perusahaan dalam menghasilkan laba selama periode tertentu. Rasio profitabilitas yaitu Return on Equity, Return on Assets, dan Net Profit Margin. Sedangkan untuk kinerja saham, dapat diukur dengan Price to Book Value dan Earning Per Share. Price to Book Value menunjukkan seberapa jauh perusahaan mampu menciptakan nilai perusahaan relatif terhadap jumlah modal yang diinvestasikan. Menurut Simamora (2000), Earning Per Share adalah laba bersih per lembar saham biasa yang beredar selama periode tertentu. Earning Per Share merupakan proksi bagi laba per saham perusahaan yang diharapkan dapat memberikan gambaran bagi investor mengenai bagian keuntungan yang dapat diperoleh dalam suatu periode tertentu dengan memiliki suatu saham. Para pemegang saham biasanya tertarik dengan angka Earning Per Share yang dilaporkan perusahaan.

Penilaian kinerja saham adalah bagian dari proses analisis sekuritas dalam investasi. Menilai kinerja saham berarti menilai kinerja perusahaan yang menerbitkan saham. Hal tersebut berarti bahwa nilai yang tercermin dalam saham adalah cerminan dari nilai perusahaan yang diapresiasi oleh pasar. Subiyantoro dan Andreani (2003) menemukan bahwa harga saham dipengaruhi oleh book value equity per share dan return on equity. Sedangkan faktor lain, seperti return on asset, debt to equity ratio, stock return, market risk, dan return on the market index tidak berpengaruh terhadap harga saham, penelitian ini menggunakan analisis regresi linier.

Penelitian ini menjadi menarik untuk dilakukan mengingat telah banyaknya penelitian mengenai pengaruh tata kelola perusahaan terhadap kinerja keuangan. Namun, hasil yang didapatkan masih beragam dengan mayoritas menyatakan bahwa Tata Kelola Perusahaan berkontribusi positif terhadap bagi perusahaan. Berdasarkan permasalahan tersebut dan latar belakang yang telah peneliti kemukakan sebelumnya, maka masalah yang teridentifikasi dalam penelitian ini di antaranya adalah terdapat perbedaan hasil penelitian dengan variabel yang relatif sama. Hal ini diduga karena adanya perbedaan teknik analisis yang digunakan oleh peneliti. Selain itu, masalah lain yang teridentifikasi adalah diduga adanya hubungan yang terjadi secara langsung antara tata kelola perusahaan dengan kinerja keuangan dan hubungan secara tidak langsung antara tata kelola perusahaan dengan kinerja saham. Sehingga, penelitian ini bertujuan untuk menganalisis pengaruh tata kelola perusahaan terhadap kinerja keuangan dan kinerja saham pada perusahaan yang terindeks LQ45 pada periode Agustus 2016 - Januari 2017.

\section{LANDASAN TEORI}

\section{Kinerja Keuangan}

Kinerja keuangan merupakan sesuatu yang dihasilkan oleh perusahaan dalam periode tertentu yang mengacu terhadap standar yang telah ditetapkan (Zarkasyi 2008). Tingkat 
kinerja perusahaan dilakukan dengan melakukan evaluasi melalui pengukuran atas apa yang dihasilkan perusahaan menggunakan ukuran-ukuran yang telah disepakati. Hasil evaluasi tersebut akan menghasilkan informasi mengenai kualitas perusahaan yang berguna baik untuk perusahaan, investor, pemerintah, dan pihak yang berkepentingan. Pengukuran kinerja perusahaan terbagi menjadi dua, yaitu pengukuran non kinerja keuangan dan pengukuran kinerja keuangan. Pengukuran kinerja non keuangan menggunakan aspek operasional dan administrasi perusahaan sebagai bahan pengukurannya, sedangkan pengukuran kinerja keuangan menggunakan analisis keuangan yang pada dasarnya dilakukan dengan melakukan evaluasi kinerja di masa lalu (Lesmana dan Surjanto 2003). Hasil evaluasi tersebut dapat dijadikan bahan peramalan kinerja keuangan untuk mengetahui prospek atau keadaan perusahaan di masa yang akan datang.

Pengukuran kinerja keuangan dilakukan dengan melihat laporan keuangan perusahaan. Salah satu metode yang sering digunakan untuk mengukur kinerja keuangan adalah melalui analisis rasio keuangan. Rasio keuangan menggambarkan hubungan antara jumlah tertentu dengan jumlah lainnya pada laporan keuangan. Setiap bentuk analisis rasio memiliki tujuan tertentu yang digunakan untuk menentukan perbedaan penekanan hubungan (Brigham dan Houston 2001), beberapa rasio keuangan diantaranya rasio likuiditas, rasio leverage, rasio profitabilitas, rasio aktivitas dan rasio pasar. Pada penelitian ini rasio yang dianalisa adalah rasio leverage yaitu Debt to Equity Ratio, Debt to Assets Ratio, rasio profitabilitas yaitu Return on Equity, Return on Assets, dan Net Profit Margin. Rasio leverage mengukur kemampuan perusahaan dalam memenuhi kewajiban jangka panjangnya. Debt to Equity Ratio merupakan bagian dari rasio leverage. Debt to Equity Ratio menggambarkan sejauh mana modal perusahaan dibiayai dengan utang. Semakin tinggi nilai Debt to Equity Ratio menunjukkan semakin tingginya permodalan perusahaan dibiayai dari dana pihak luar (hutang). Hal ini juga memperbesar tingkat risiko yang akan dihadapi perusahaan. Selain DER, yang termasuk rasio leverage adalah Debt to Asset Ratio. Debt to Asset Ratio. adalah sejauh mana aset perusahaan dibiayai dari dana pihak luar (utang). Nilai Debt to Asset Ratio yang semakin besar juga akan memperbesar risiko yang akan dihadapi perusahaan.

Risiko yang dimaksud terkait dengan kemampuan perusahaan dalam membayar beban atas hutang tersebut. Kedua indikator ini merupakan indikator yang sering dipertimbangkan investor dalam memutuskan berinvestasi pada sebuah perusahaan. Sehingga perusahaan harus mampu menjaga rasio ini sesuai standar agar mampu menjadi indikator yang mendukung investor untuk menanamkan modalnya. Rasio profitabilitas menggambarkan kemampuan perusahaan dalam mencetak laba. Laba merupakan faktor penting dalam penentuan jumlah deviden yang diperoleh investor. Laba adalah tujuan utama investor menanamkan modalnya pada suatu perusahaan sehingga majanemen perusahaan harus mampu menghasilkan laba sesuai tujuan investor. Rasio ini dapat dilihat dari beberapa indikator diantaranya ROE, ROA dan NPM. ROE merupakan rasio untuk mengukur laba bersih dengan ekuitas pada saham biasa atau tingkat pengembalian investasi pemegang saham. ROE dapat dijadikan sebagai indikator seberapa baiknya kinerja manajemen perusahaan dalam mengelolah modal dari investor. Sedangkan Return on Assets mengukur laba bersih dengan aset. Net Profit Margin merupakan rasio profitabilitas. Rasio ini menggambarkan sejauh mana laba bersih perusahaan. Semakin tinggi rasio-rasio ini, kinerja laba perusahaan semakin baik. Artinya posisi pemilik perusahaan semakin kuat, demikian pula sebaliknya. 


\section{Kinerja Saham}

Kinerja saham dapat diukur dengan beberapa rasio. Rasio yang dapat digunakan untuk mengukur kinerja saham adalah Price to Book Value dan Earning Per Share. Price to Book Value merupakan bagian dari rasio pasar yang mengukur harga pasar relatif terhadap nilai buku. Price to Book Value adalah rasio yang membandingkan antara nilai saham menurut pasar dengan harga saham berdasar harga buku (book value). Price to Book Value digunakan untuk melihat berapa besar tingkat undervalued maupun overvalued harga saham yang dihitung berdasarkan nilai buku setelah dibandingkan dengan harga pasar. Rasio ini menunjukkan seberapa jauh perusahaan mampu menciptakan nilai perusahaan relatif terhadap jumlah modal yang diinvestasikan.

Menurut Simamora (2000), Earning Per Share adalah laba bersih per lembar saham biasa yang beredar selama periode tertentu. Earning Per Share atau laba per lembar saham adalah tingkat keuntungan bersih untuk tiap lembar sahamnya yang mampu diraih perusahaan pada saat menjalankan operasinya. Variabel Earning Per Share merupakan proksi bagi laba per saham perusahaan yang diharapkan dapat memberikan gambaran bagi investor mengenai bagian keuntungan yang dapat diperoleh dalam suatu periode tertentu dengan memiliki suatu saham. Tujuan investor dalam menanamkan modalnya pada suatu perusahaan adalah mendapatkan deviden atau capital gain. Laba biasanya menjadi dasar penentuan pembayaran deviden atau kenaikan nilai saham di masa mendatang. Oleh sebab itu, para pemegang saham biasanya tertarik dengan angka Earning Per Share yang dilaporkan perusahaan.

\section{Corporate Governance (Tata Kelola Perusahaan)}

Kata "governance" berasal dari bahasa Prancis yaitu "gubernance" yang memiliki arti pengendalian. Dari kata tersebut muncul suatu istilah corporate governance yang dipergunakan dalam konteks perusahaan atau organisasi. Terminologi corporate governance memiliki pengertian dasar yaitu suatu sistem yang mengarahkan dan mengendalikan kegiatan perusahaan (Sutojo dan Aldridge 2008). Dalam konteks Indonesia, corporate governance dikenal dengan istilah tata kelola perusahaan. Muncul berbagai pengertian tata kelola perusahaan yang diungkapkan para ahli maupun organisasi yang fokus terhadap tata kelola perusahaan dari pengertian dasar tersebut. Pengertian tata kelola perusahaan yang sering dikutip para peneliti dan penulis yaitu pengertian dari Cadbury (1992) yang menyatakan tata kelola perusahaan sebagai suatu sistem dimana perusahaan diarahkan dan dikendalikan oleh dewan direksi sebagai suatu tanggung jawab yang diberikan para pemegang saham dengan tujuan memuaskan kepentingan pemegang saham. Teori tata kelola perusahaan muncul sebagai jawaban atas permasalahan keagenan di antara prinsipal (pemegang saham) dan agen (perusahaan / dewan direksi / manajer) yang mempunyai kepentingan berbeda. Namun ternyata konflik yang dihadapi perusahaan semakin melebar. Konflik perusahaan tidak hanya berhenti di lingkup internal perusahaan, pihak eksternal baik yang terlibat secara langsung maupun tidak langsung juga berpotensi menimbulkan konflik. Pihak eksternal tersebut dikenal dengan istilah pemangku kepentingan (stakeholder).

Berdasarkan kondisi tersebut, perspektif tata kelola perusahaan semakin meluas yang berlandaskan pada stakeholder theory. Cadbury pun merevisi pengertian tata kelola perusahaan menjadi suatu prinsip yang mengarahkan dan mengendalikan perusahaan agar mencapai keseimbangan antara kekuatan serta kewenangan perusahaan dalam memberikan pertanggungjawaban kepada para pemegang saham khususnya dan stakeholder pada umumnya (Cadbury dalam Dewi dan Widagdo 2012). Forum for Corporate Governance in Indonesia, suatu lembaga yang bertujuan meningkatkan dan mensosialisasikan tata 
kelola perusahaan pada komunitas bisnis di Indonesia, mendefinsikan tata kelola perusahaan sebagai seperangkat aturan pengarahan dan pengendalian yang menetapkan hubungan antara pemegang saham, manajer, pihak kreditur, pemerintah, karyawan, serta para pemangku kepentingan internal dan eksternal lainnya (FCGI 2013). Dari beberapa pengertian tersebut, dapat ditarik kesimpulan bahwa tata kelola perusahaan bekerja dengan cara mendefinisikan hak dan kewajiban setiap partisipan, kemudian diadakan pengendalian agar partisipan bekerja sesuai porsinya sehingga tujuan akhir dapat tercapai yang akan menguntungkan setiap partisipan yang terlibat.

\section{Tujuan dan Manfaat Tata Kelola Perusahaan}

Menurut Sutojo dan Aldridge (2008), penerapan tata kelola perusahaan mempunyai lima tujuan utama, yaitu: a) Melindungi hak dan kepentingan pemegang saham. b) Melindungi hak dan kepentingan stakeholder non pemegang saham. c) Meningkatkan nilai perusahaan dan pemegang saham. d) Meningkatkan efisiensi dan efektivitas kerja dewan pengurus atau board of director dan manajemen perusahaan. e) Meningkatkan mutu hubungan board of director dengan manajemen senior perusahaan.

Berdasarkan hasil studi empiris yang dilakukan para peneliti telah ditemukan buktibukti bahwa tata kelola perusahaan memberikan kontribusi positif bagi perusahaan. Melalui kontribusi positif tersebut dapat tercapailah tujuan perusahaan di dalam menerapkan tata kelola perusahaan. Beberapa hasil studi tersebut adalah sebagai berikut: a) Penelitian Brown and Caylor (2004) ditemukan bahwa perusahaan dengan good corporate governance menghasilkan laba yang lebih tinggi, memiliki risiko bisnis yang lebih rendah, dan menuai return saham yang lebih tinggi jika dibandingkan perusahaan dengan bad corporate governance. b) Studi empiris yang dilakukan di Jerman menunjukkan bahwa perusahaan dengan good corporate governance lebih mampu meningkatkan market-tobook ratio-nya yang berarti perusahaan dapat meningkatkan kapitalisasi pasarnya (Drobetz et al. 2003). c) Penelitian Coombes and Watson (2000) menyimpulkan bahwa investasi dipertimbangkan lebih aman dan terlindungi jika dilakukan pada perusahaan yang menerapkan tata kelola perusahaan.

Namun terlepas dari manfaat yang telah diungkapkan diatas, manfaat optimal tata kelola perusahaan akan berbeda dari satu perusahaan terhadap perusahaan lainnya. Hal ini dikarenakan perbedaan faktor-faktor intern perusahaan, termasuk riwayat perusahaan, jenis usaha, jenis risiko, strukur permodalan, dan struktur manajemen. Oleh karena itu, perusahaan harus memodifikasi penerapan tata kelola perusahaan yang disesuaikan dengan kondisi perusahaannya.

\section{Partisipan Tata Kelola Perusahaan}

Partisipan tata kelola perusahaan merupakan organ perusahaan yang berperan untuk menegakkan tata kelola perusahaan di perusahaan dan melaksanakannya secara efektif. Partisipan tata kelola perusahaan terdiri dari pemegang saham, dewan komisaris, dewan direksi, komite audit, dan stakeholder lainnya. Masing-masing partisipan akan menentukan arah perkembangan dan kebijakan perusahaan dalam penerapan tata kelola perusahaan melalui tugas dan tanggung jawabnya. Dengan kata lain, kualitas penerapan tata kelola perusahaan dapat diukur berdasarkan apa yang dilaksanakan partisipan dan bagaimana partisipan berupaya untuk menjalankan fungsinya sesuai dengan prinsip-prinsip tata kelola perusahaan (Warsono et al.2009). Pemegang saham sebagai bagian dari partisipan tata kelola perusahaan memiliki hak dan tanggung jawab atas perusahaan sesuai dengan peraturan perundang-undangan yang berlaku. 
Kepemilikan saham di dalam suatu perusahaan dapat mempengaruhi penerapan tata kelola perusahaan tergantung dari bentuk kepemilikannya. Kepemilikan saham diantaranya dapat berbentuk kepemilikan manajerial dan kepemilikan terkonsentrasi. Kepemilikan manajerial merupakan saham yang dimiliki oleh pihak manajemen perusahaan. Kepemilikan terkonsentrasi merupakan kepemilikan saham dimana lebih dari 50\% saham perusahaan dimiliki oleh satu pihak baik perorangan maupun lembaga. Dewan komisaris adalah organ perusahaan yang bertugas melakukan pengawasan secara umum maupun khusus kepada dewan direksi dalam melaksanakan tugasnya sesuai dengan anggaran dasar. Sedangkan dewan direksi adalah organ perusahaan yang berwenang dan bertanggung jawab atas pengelolaan perusahaan dalam rangka mencapai maksud dan tujuan perusahaan.

Menurut Undang-Undang Perseroan Terbatas Nomor 40 tahun 2007 pasal 108 ayat 5 dijelaskan bahwa bagi perusahaan berbentuk perseroan terbatas wajib memiliki paling sedikitnya 2 (dua) anggota dewan komisaris. Dewan Komisaris terdiri dari komisaris independen dan komisaris nonindependen. Komisaris independen adalah komisaris yang tidak termasuk ke dalam anggota manajemen, pemegang saham, pemasok, pelanggan, dan harus bebas dari kepentingan maupun bisnis apapun yang berhubungan dengan perusahaan. Komposisi dari komisaris independen telah diatur oleh Bursa Efek Indonesia (BEI) per tanggal 1 juli 2000 bagi perusahaan yang listing di bursa dengan proporsi minimal 30\% dari jumlah seluruh anggota komisaris. Komposisi dewan komisaris yang dibentuk haruslah mendukung proses pengambilan keputusan yang efektif, tepat, dan cepat.

\section{Penerapan Corporate Governance}

Selama tahun 1990-an, isu mengenai tata kelola perusahaan hampir tidak terdengar. Ketika keuntungan dan harga saham perusahaan naik secara substansial, investor lupa mengenai pentingnya tata kelola perusahaan. Namun di akhir tahun 1990 dan di awal tahun 2000, investor kembali tersadar ketika pasar saham jatuh dan perusahaan-perusahaan besar runtuh akibat tidak menerapkan tata kelola perusahaan dengan baik (Proimos 2005). Bisa kita lihat skandal spektakuler yang mengejutkan bagaimana perusahaan kelas dunia seperti Enron, Worldcom, Tyco, London \& Commonwealth, Poly Peck, dan Maxwell mengalami keruntuhan akibat praktek curang dari manajemen puncak tidak terdeteksi dalam waktu yang cukup lama karena lemahnya penerapan tata kelola perusahaan (Santosa 2008).

Lemahnya penerapan tata kelola perusahaan juga terjadi di Indonesia yang menyebabkan terjadinya krisis pada tahun 1997 yang telah menghancurkan berbagai sektor perekonomian. Melihat dampak yang sangat besar tersebut, penerapan tata kelola perusahaan kembali digiatkan sebagai suatu langkah preventif untuk mengawasi dan mengontrol kegiatan perusahaan. Langkah pemerintah Indonesia dalam menggiatkan tata kelola perusahaan di antaranya dengan pembentukan komite dan mengeluarkan regulasi terkait tata kelola perusahaan. Pada tahun 2004 melalui keputusan Menteri Koordinator Perekonomian RI No. KEP-49/M.EKON/11/TAHUN 2004 dibentuk Komite Nasional Kebijakan Governance (KNKG) dengan misi mendorong dan meningkatkan efektivitas penerapan good governance di Indonesia dalam rangka membangun kultur yang berwawasan good governance, baik di sektor publik maupun korporasi (KNKG 2013). Kemudian pada tanggal 15 Agustus 2007 pemerintah juga mengeluarkan Undang-Undang Perseroan Terbatas (PT) No. 40 yang menuntut perusahaan untuk menerapkan tata kelola perusahaan sebagai bagian dari kewajiban. 


\section{METODE PENELITIAN}

Penelitian ini menggunakan desain eksplanatif asosiatif yang bertujuan memberikan gambaran mengenai pola yang digunakan dan menguji kebenaran hubungan antar variable. Populasi penelitian ini adalah perusahaan yang tercatat pada Bursa Efek Indonesia dan dilakukan purposive sampling dengan kriteria perusahaan yang terdaftar pada indeks saham LQ45 periode Agustus 2016 - Januari 2017 sehingga didapatkan sampel sebanyak 45 perusahaan. Pengumpulan data dilakukan dengan mengolah data sekunder yang bersumber dari laporan keuangan dan laporan tahunan yang telah dipublikasikan di website Bursa Efek Indonesia (BEI).

Variabel diuji menggunakan analisis Structural Equation Modelling (SEM) dengan pendekatan varian atau yang biasa dikenal sebagai partial least square path modelling dan menggunakan software smartPLS. Kelebihan dari smartPLS adalah dapat melakukan analisis dengan keterbatasan jumlah sampel dengan model kompleks (Yamin dan Kurniawan 2009). Analisis SEM memiliki tiga tahapan utama, yaitu pengembangan dan analisis model pengukuran, pengembangan dan analisis model struktural, dan interpretasi hasil analisis. Tiap tahapan memiliki alur masing-masing, tahap pertama terdiri dari menetapkan model pengukuran awal, merancang studi empiris, memeriksa data, mengevaluasi model, dan memperbaiki model pengukuran jika diperlukan. Tahapan kedua terdiri dari menetapkan model struktural, mengevaluasi model, memperbaiki model jika diperlukan, dan uji hipotesis relasi struktural (Dachlan 2014). Tahap pertama yang perlu dilakukan adalah menetapkan model pengukuran awal, dalam penelitian ini model pengukuran awal yang menjadi acuan untuk melakukan uji konfirmasi adalah sebagai berikut :

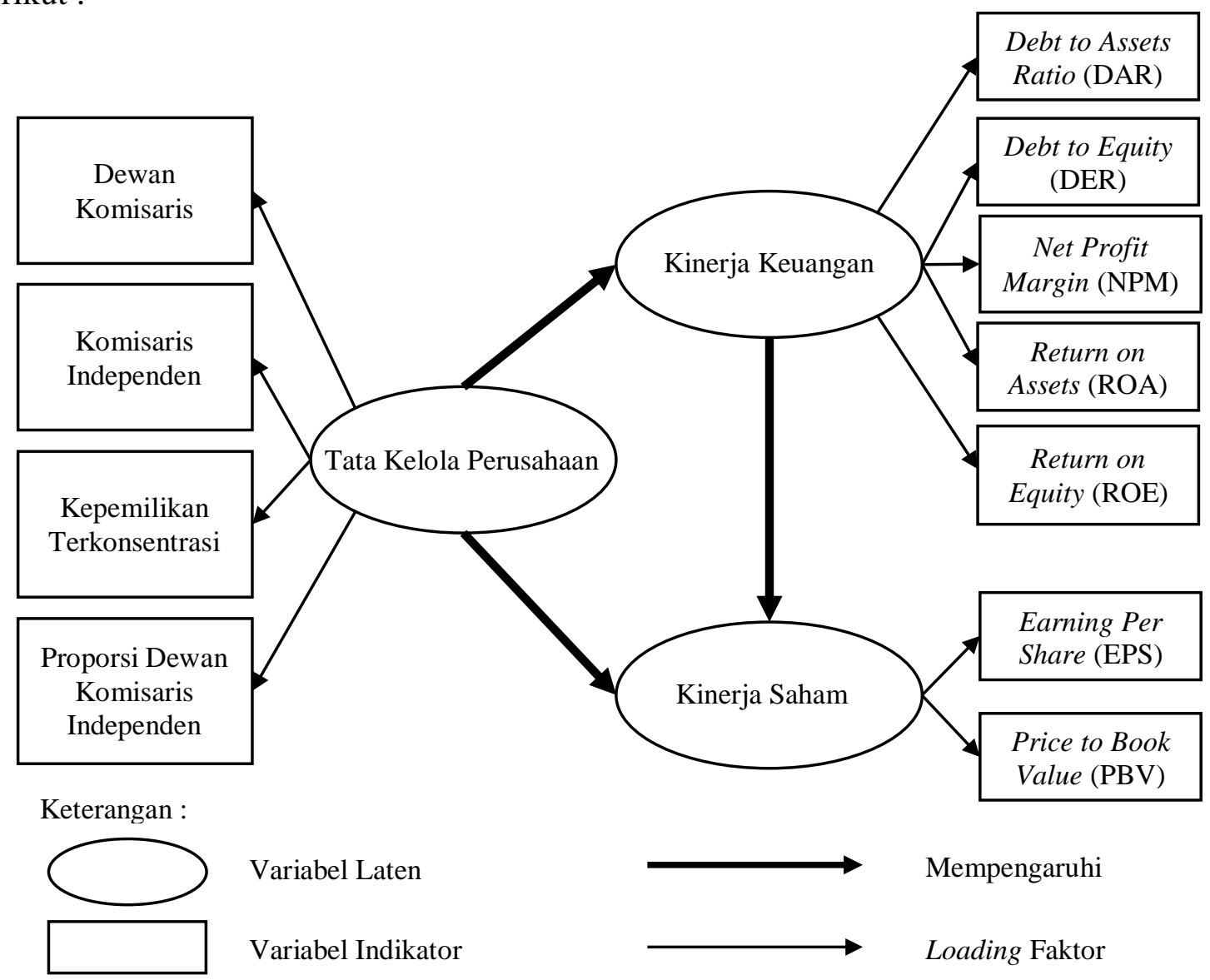

Gambar 1 Model pengukuran awal 


\section{HASIL DAN PEMBAHASAN}

\section{Gambaran Objek Penelitian}

Menurut Undang-Undang Perseroan Terbatas Nomor 40 Tahun 2007 pasal 108 ayat 5 dijelaskan bahwa perusahaan berbentuk perseroan terbatas wajib memiliki paling sedikitnya dua (2) anggota dewan komisaris. Berdasarkan Tabel 1 di bawah ini terlihat bahwa semua perusahaan telah memiliki anggota dewan komisaris paling sedikitnya 2 orang. Rata-rata jumlah anggota dewan komisaris pada perusahaan terindeks LQ45 periode Agustus 2016 - Januari 2017 sebanyak 6 orang. Dewan komisaris memiliki fungsi sebagai pengendali internal tertinggi di dalam perusahaan. Semakin banyak jumlah anggota dewan komisaris diharapkan mampu meningkatkan kegiatan monitoring, sehingga tata kelola perusahaan dapat dilaksanakan dengan lebih baik. Adanya kegiatan monitoring yang dilakukan oleh dewan komisaris dapat meningkatkan rasa kepatuhan dari perusahaan dalam menjalankan kegiatan operasional sesuai dengan aturan-aturan yang berlaku.

Bursa Efek Indonesia (BEI) per tanggal 1 Juli 2000 telah menetapkan bahwa perusahaan yang masuk pada bursa harus memiliki proporsi dewan komisaris independen sebanyak 30 persen dari jumlah seluruh anggota komisaris. Pada Tabel 1 terlihat bahwa terdapat satu perusahaan yang memiliki komposisi proporsi dewan komisaris independen di bawah 30 persen dan menjadi perusahaan dengan proporsi dewan komisaris independen terkecil $(22,22 \%)$. Perusahaan tersebut adalah perusahaan Vale Indonesia dengan jumlah dewan komisaris sebanyak 9 orang, sedangkan jumlah komisaris independen pada perusahaan tersebut sebanyak 2 orang. Perusahaan yang terindeks LQ45 periode Agustus 2016 - Januari 2017 rata-rata memiliki proporsi dewan komisaris independen sebanyak 43 persen. Komisaris independen diperlukan dalam rangka meningkatkan independensi dewan komisaris terhadap kepentingan manajerial maupun kepentingan pemegang saham mayoritas. Komisaris independen harus menempatkan dirinya untuk kepentingan perusahaan dan kepentingan shareholder secara berimbang dan tidak memihak. Semakin besar proporsi dewan komisaris independen, maka keputusan yang diambil oleh dewan komisaris akan semakin objektif dan transparan.

Tabel 1 Hasil olah data variabel penelitian

\begin{tabular}{cccccccrrrrr}
\hline Kode & $\begin{array}{c}\text { DK } \\
(\mathbf{o r g})\end{array}$ & $\begin{array}{c}\text { KI } \\
(\mathbf{o r g})\end{array}$ & $\begin{array}{c}\text { KT } \\
(\boldsymbol{\%})\end{array}$ & $\begin{array}{c}\text { PDKI } \\
(\boldsymbol{\%})\end{array}$ & DAR & DER & NPM & ROA & ROE & EPS & PBV \\
\hline AALI & 5 & 2 & 79,68 & 40,00 & 0,35 & 0,55 & 12,84 & 3,21 & 4,96 & 823,13 & 1,94 \\
ADHI & 6 & 2 & 51,00 & 33,33 & 0,70 & 2,35 & 1,78 & 0,33 & 1,09 & 15,60 & 1,94 \\
ADRO & 5 & 2 & 49,91 & 40,00 & 0,43 & 0,76 & 10,46 & 2,04 & 3,58 & 50,32 & 0,76 \\
AKRA & 3 & 1 & 59,17 & 33,33 & 0,48 & 0,94 & 8,40 & 4,02 & 7,79 & 146,75 & 3,43 \\
ANTM & 6 & 2 & 65,00 & 33,33 & 0,38 & 0,62 & 0,26 & 0,04 & 0,06 & 0,46 & 0,98 \\
ASII & 12 & 4 & 50,11 & 33,33 & 0,48 & 0,92 & 9,42 & 3,33 & 6,39 & 175,79 & 2,60 \\
ASRI & 5 & 2 & 48,42 & 40,00 & 0,62 & 1,64 & 43,54 & 2,97 & 7,83 & 28,40 & 1,39 \\
BBCA & 4 & 2 & 45,13 & 50,00 & 0,83 & 5,02 & 38,64 & 1,53 & 9,25 & 388,40 & 3,62 \\
BBNI & 9 & 5 & 60,00 & 55,56 & 0,81 & 5,25 & 21,50 & 0,82 & 5,31 & 234,41 & 1,31 \\
BBRI & 9 & 5 & 56,75 & 55,56 & 0,85 & 5,79 & 26,06 & 1,34 & 9,11 & 493,55 & 2,17 \\
BBTN & 7 & 4 & 60,00 & 57,14 & 0,91 & 9,80 & 12,84 & 0,55 & 5,94 & 98,42 & 1,20 \\
BMRI & 8 & 5 & 60,00 & 62,50 & 0,79 & 5,23 & 20,63 & 0,77 & 5,10 & 303,44 & 1,81 \\
BMTR & 5 & 3 & 45,60 & 60,00 & 0,42 & 0,72 & 19,51 & 4,05 & 6,96 & 42,37 & 0,84 \\
BSDE & 5 & 2 & 48,42 & 40,00 & 0,39 & 0,64 & 31,55 & 2,40 & 3,94 & 42,70 & 1,87 \\
CPIN & 4 & 2 & 55,53 & 50,00 & 0,46 & 0,85 & 9,11 & 6,81 & 12,57 & 105,62 & 4,55 \\
ELSA & 5 & 2 & 41,10 & 40,00 & 0,32 & 0,47 & 11,14 & 2,55 & 3,75 & 12,85 & 1,36 \\
GGRM & 4 & 2 & 69,29 & 50,00 & 0,44 & 0,77 & 7,77 & 4,52 & 8,01 & 1491,21 & 3,53 \\
HMSP & 5 & 2 & 92,00 & 40,00 & 0,29 & 0,42 & 12,99 & 15,63 & 22,15 & 5285,54 & 17,01 \\
ICBP & 6 & 3 & 80,00 & 50,00 & 0,39 & 0,65 & 11,27 & 7,34 & 12,12 & 339,44 & 6,56 \\
INCO & 9 & 2 & 58,73 & 22,22 & 0,18 & 0,22 & $(8,12)$ & $(0,90)$ & $(1,10)$ & $(26,59)$ & 1,12 \\
INDF & 8 & 3 & 50,07 & 37,50 & 0,53 & 1,13 & 8,09 & 2,97 & 6,31 & 254,09 & 1,56 \\
\hline
\end{tabular}




\begin{tabular}{cccccccrrrrr}
\hline Kode & $\begin{array}{c}\text { DK } \\
(\mathbf{o r g})\end{array}$ & $\begin{array}{c}\text { KI } \\
(\mathbf{o r g})\end{array}$ & $\begin{array}{c}\text { KT } \\
\boldsymbol{( \% )}\end{array}$ & $\begin{array}{c}\text { PDKI } \\
\boldsymbol{( \% )}\end{array}$ & DAR & DER & NPM & ROA & ROE & EPS & PBV \\
\hline INTP & 7 & 3 & 51,00 & 42,86 & 0,11 & 0,12 & 31,38 & 8,74 & 9,81 & 659,88 & 2,78 \\
JSMR & 6 & 2 & 70,00 & 33,33 & 0,67 & 2,00 & 13,03 & 2,17 & 6,52 & 124,89 & 2,72 \\
KLBF & 7 & 3 & 10,17 & 42,86 & 0,21 & 0,27 & 12,27 & 8,24 & 10,44 & 24,45 & 7,45 \\
LPKR & 7 & 5 & 15,93 & 71,43 & 0,54 & 1,16 & 15,04 & 1,75 & 3,78 & 21,57 & 1,36 \\
LPPF & 9 & 3 & 20,48 & 33,33 & 0,81 & 4,20 & 22,34 & 21,88 & 113,84 & 396,55 & 57,99 \\
LSIP & 6 & 2 & 59,48 & 33,33 & 0,17 & 0,21 & 6,81 & 1,29 & 1,56 & 16,51 & 1,53 \\
MNCN & 5 & 2 & 60,70 & 40,00 & 0,34 & 0,50 & 30,08 & 7,27 & 10,94 & 70,20 & 2,87 \\
MPPA & 7 & 3 & 50,23 & 42,86 & 0,64 & 1,74 & $(0,30)$ & $(0,29)$ & $(0,79)$ & $(3,86)$ & 4,22 \\
MYRX & 3 & 1 & 15,02 & 33,33 & 0,25 & 0,33 & 37,13 & 3,82 & 5,07 & 20,25 & 2,02 \\
PGAS & 6 & 2 & 56,96 & 33,33 & 0,54 & 1,17 & 10,76 & 2,37 & 5,13 & 82,89 & 1,95 \\
PTBA & 6 & 2 & 65,02 & 33,33 & 0,45 & 0,81 & 10,57 & 4,30 & 7,76 & 308,91 & 2,42 \\
PTPP & 5 & 2 & 51,00 & 40,00 & 0,74 & 2,78 & 6,34 & 2,01 & 7,58 & 11,43 & 4,06 \\
PWON & 3 & 2 & 20,90 & 66,67 & 0,49 & 0,95 & 39,41 & 4,83 & 9,43 & 18,60 & 2,95 \\
SCMA & 5 & 2 & 60,97 & 40,00 & 0,23 & 0,30 & 35,91 & 16,81 & 21,84 & 57,24 & 11,55 \\
SILO & 6 & 3 & 60,46 & 50,00 & 0,44 & 0,79 & 3,07 & 2,42 & 4,32 & 60,01 & 6,73 \\
SMGR & 7 & 2 & 51,01 & 28,57 & 0,30 & 0,42 & 15,97 & 5,09 & 7,23 & 331,28 & 2,26 \\
SMRA & 4 & 2 & 12,86 & 50,00 & 0,62 & 1,60 & 5,65 & 0,66 & 1,73 & 1,70 & 3,52 \\
SRIL & 3 & 1 & 56,07 & 33,33 & 0,65 & 1,89 & 8,62 & 3,76 & 10,87 & 22,68 & 1,28 \\
SSMS & 2 & 1 & 28,24 & 50,00 & 0,55 & 1,22 & 30,15 & 2,11 & 4,68 & 15,65 & 4,95 \\
TLKM & 7 & 3 & 51,19 & 42,86 & 0,45 & 0,81 & 25,97 & 8,55 & 15,46 & 98,47 & 4,47 \\
UNTR & 6 & 2 & 59,50 & 33,33 & 0,33 & 0,49 & 8,31 & 3,18 & 4,73 & 496,91 & 1,67 \\
UNVR & 5 & 4 & 84,99 & 80,00 & 0,74 & 2,87 & 15,90 & 17,43 & 67,44 & 432,27 & 72,39 \\
WIKA & 7 & 2 & 65,05 & 28,57 & 0,73 & 2,67 & 5,06 & 1,49 & 5,46 & 41,71 & 3,67 \\
WSKT & 6 & 2 & 66,04 & 33,33 & 0,75 & 2,94 & 7,20 & 1,44 & 5,67 & 43,19 & 3,65 \\
\hline
\end{tabular}

Rasio solvabilitas menggunakan indikator DAR dan DER dalam mengukur kinerja keuangan perusahaan. Nilai DAR terbesar adalah perusahaan Bank Tabungan Negara (BBTN) dengan nilai DAR hampir mendekati nilai $1(0,91)$. Hal tersebut berarti total hutang yang dimiliki oleh perusahaan Bank Tabungan Negara hampir sama dengan besarnya total asset yang dimiliki oleh perusahaan tersebut. Hal ini akan meningkatkan risiko yang dimiliki oleh perusahaan tersebut dalam menjalankan perusahaannya. Nilai DAR terkecil diperoleh perusahaan Indocement Tunggal Prakasa (INTP) sebesar 0,11 yang berarti bahwa total hutang perusahaan Indocement Tunggal Prakasa lebih kecil dibandingkan dengan aset yang dimiliki perusahaan tersebut.

Nilai DER terbesar adalah perusahaan Bank Tabungan Negara (BBTN) sebesar 9,80. Hal ini menunjukkan bahwa perusahaan Bank Tabungan Negara memiliki ketergantungan yang paling besar terhadap hutang untuk membiayai modal dibandingkan dengan perusahaan lainnya yang terindeks dalam indeks LQ45 periode Agustus 2016 - Januari 2017. Sedangkan nilai DER terkecil diperoleh perusahaan Indocement Tunggal Prakasa (INTP) sebesar 0,12. Nilai ini menunjukkan bahwa perusahaan Indocement Tunggal Prakasa memiliki ketergantungan paling rendah terhadap hutang untuk membiayai modal perusahaan dibandingkan dengan perusahaan lainnya yang terindeks dalam indeks LQ45 periode Agustus 2016 - Januari 2017.

Rasio profitabilitas menggunakan indikator ROA, ROE, dan NPM untuk mengukur kinerja keuangan perusahaan. ROA menunjukkan kemampuan perusahaan dalam memaksimalkan efektivitas dan efisiensi aktiva untuk memperoleh keuntungan. Semakin besar nilai ROA, maka semakin besar pula keuntungan yang diperoleh perusahaan. Nilai ROA yang terkecil diperoleh perusahaan Vale Indonesia (INCO) dengan nilai minus 0,90 dan nilai terbesar diperoleh perusahaan Matahari Departement Store (LPPF) sebesar 21,88. Nilai minus yang diperoleh perusahaan Vale Indonesia mengindikasikan bahwa perusahaan tersebut mengalami kerugian. Lestari dan Sugiharto (2007) mengemukakan 
bahwa ROA dikatakan baik jika memiliki nilai lebih dari dua persen (2\%). Lebih dari separuh $(69 \%)$ perusahaan yang terindeks dalam LQ45 periode Agustus 2016 - Januari 2017 memiliki nilai ROA yang baik dan terdapat dua perusahaan yang mengalami kerugian dengan nilai ROA minus. Perusahaan yang mengalami kerugian adalah perusahaan Vale Indonesia (INCO) dan perusahaan Matahari Putra Prima (MPPA).

Rasio ROE digunakan untuk mengukur keberhasilan perusahaan dalam menghasilkan laba bagi para pemegang saham (Subiyanto 2009). Semakin tinggi nilai ROE maka deviden yang didapatkan oleh pemegang saham juga tinggi. Sehingga, ROE menjadi salah satu alat utama investor untuk menilai kelayakan suatu saham perusahaan. Pada indikator ROE, perusahaan dengan nilai terkecil adalah Vale Indonesia (INCO) dengan nilai minus 1,10 yang berarti bahwa perusahaan Vale Indonesia memiliki tingkat pengembalian atas modal terkecil dibandingkan dengan perusahaan sampel lainnya. Dilihat dari nilai tersebut maka dapat dikatakan bahwa perusahaan Vale Indonesia mengalami kerugian pada tahun 2016. Sedangkan nilai ROE terbesar adalah 113,84 yang diperoleh perusahaan Matahari Departement Store (LPPF). ROE dikategorikan baik jika bernilai lebih dari 12 persen (Lestari dan Sugiharto 2007). Terdapat tujuh (7) perusahaan sampel yag memiliki nilai ROE di atas 12 persen. Sehingga dapat dikatakan bahwa kurang dari seperlima perusahaan yang masuk ke dalam indeks LQ45 periode Agustus 2016 - Januari 2017 memiliki ROE terkategori baik.

Net Profit Margin (NPM) merupakan rasio yang menunjukkan persentase laba bersih yang didapatkan dari hasil penjualan. Semakin besar nilai NPM maka menunjukkan bahwa kinerja perusahaan semakin produktif. Laba bersih (NPM) terkecil diperoleh perusahaan Vale Indonesia (INCO) dengan nilai minus 8,12 persen dan perusahaan Alam Sutera Realty (ASRI) yang memperoleh laba bersih sebesar 43,54 persen. Fahmi (2012) menyatakan bahwa rata-rata perusahaan menginginkan nilai NPM lebih dari 20 persen. Hanya ada 14 perusahaan sampel yang mencapai nilai NPM lebih dari 20 persen. Hal tersebut menunjukkan bahwa hanya sepertiga perusahaan terindeks LQ45 periode Agustus 2016 - Januari 2017 yang memiliki nilai NPM lebih dari 20 persen. Kemampuan perusahaan dalam mencetak nilai laba bersih (NPM) merupakan sebuah keunggulan yang menjadi daya tarik bagi investor untuk berinvestasi pada perusahaan tersebut.

\section{Analisa Model Penelitian}

Yamin dan Kurniawan (2009) mengatakan bahwa evaluasi model pengukuran adalah evaluasi hubungan antar konstruk laten dengan indikatornya. Penelitian ini menggunakan model outer-reflective. Model reflektif mengukur sejauh mana variabel dapat dimanifestasikan ke dalam indikator-indikatornya. Analisis model outer-reflective dapat dilakukan dengan dua tahap, yaitu evaluasi terhadap convergent validity dan discriminant validity. Convergent validity dapat dievaluasi dengan tiga tahap, yaitu loading factor, average variance extracted (AVE) dan composite reliability (reliabilitas konstruk).

Peubah laten Tata Kelola Perusahaan (tk) memiliki indikator ukuran dewan komisaris $(\mathrm{dk})$, komisaris independen (ki), kepemilikan terkonsentrasi (kt), dan proporsi dewan komisaris independen (pdki). Peubah laten Kinerja Keuangan (kk) menggunakan indikator DAR, DER, NPM, ROA, dan ROE. Peubah laten Kinerja Saham (ks) menggunakan indikator EPS dan PBV. 


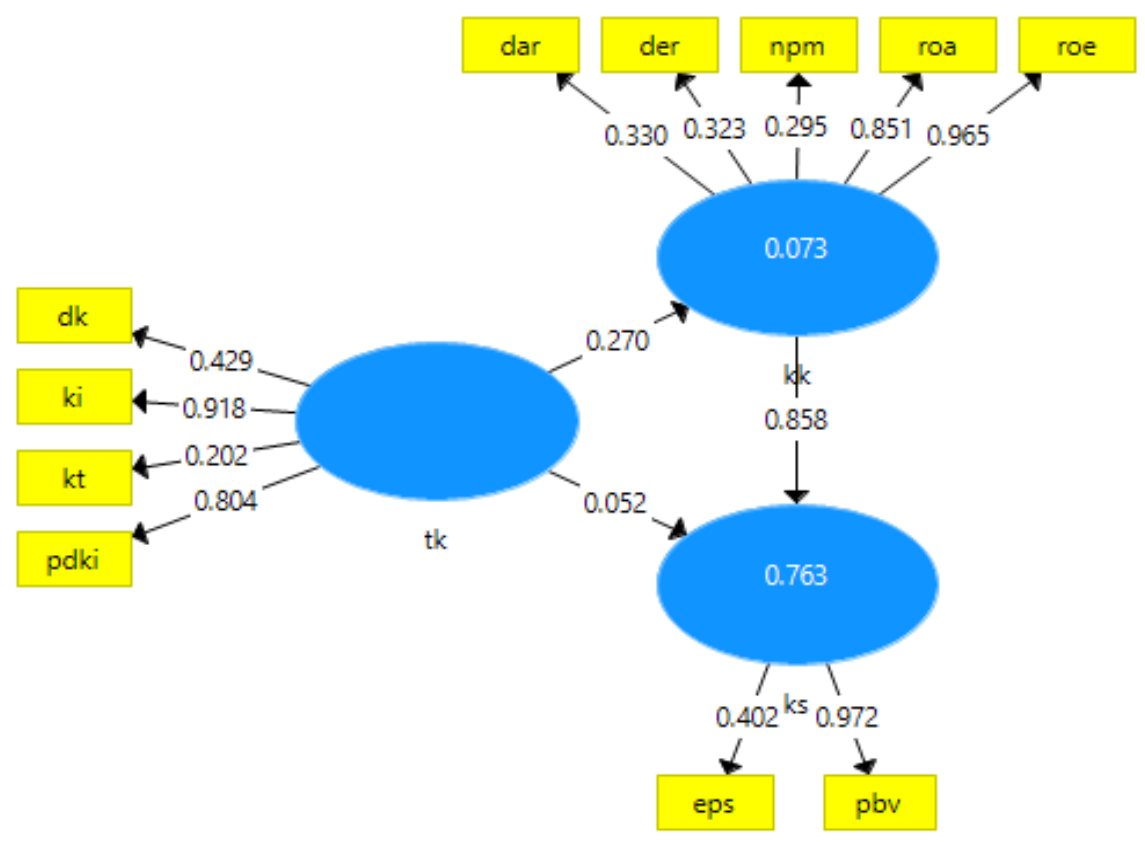

Gambar 2 Model awal

Perbaikan model dilakukan dengan melihat koefisien peubah laten dengan indikatornya. Ghozali (2008) menyatakan bahwa indikator yang memiliki nilai loading factor di bawah 0,7 harus dikeluarkan dari model. Analisa model awal menggunakan seluruh variabel penelitian, sehingga didapatkan seperti yang tertera pada Gambar 2 Model awal. Setelah didapatkan nilai loading factor masing-masing indikator, maka langkah selanjutnya adalah menghapus indikator dengan nilai loading factor terkecil dari masingmasing peubah laten. Proses ini terus dilakukan sampai dengan ditemukan suatu model yang tidak memiliki nilai loading factor di bawah 0,7. Penelitian ini melakukan iterasi (tahapan penghapusan indikator) sebanyak enam kali untuk mendapatkan model akhir seperti Gambar 3 Model akhir.

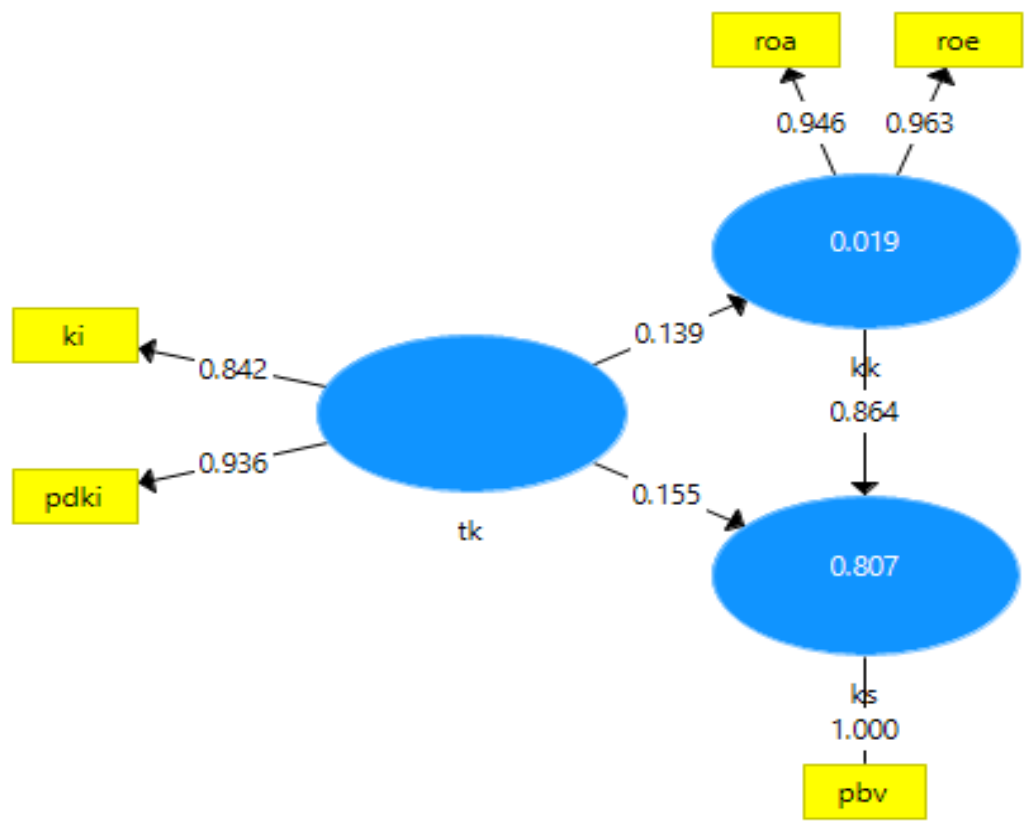

Gambar 3 Model akhir 
Hasil analisis model akhir menunjukkan indikator yang memiliki nilai loading factor di atas 0,7 untuk peubah laten Tata Kelola Perusahaan adalah komisaris independen dan proporsi dewan komisaris independen dengan nilai 0,842 dan 0,936. Nilai loading factor lebih dari 0,7 menunjukkan bahwa indikator-indikator tersebut memiliki hubungan yang valid dalam mengukur konstruknya. Nilai outer loading ditunjukkan pada Tabel 2.

Tabel 2 Nilai outer loadings

\begin{tabular}{cccc}
\hline Variabel & Tata Kelola Perusahaan & Kinerja Keuangan & Kinerja Saham \\
\hline Komisaris Independen & 0,842 & - & - \\
Proporsi Dewan Komisaris Independen & 0,936 & - & - \\
ROA & - & 0,946 & - \\
ROE & - & 0,963 & - \\
PBV & - & - & 1,000 \\
\hline
\end{tabular}

Pada model awal, indikator dengan nilai loading factor di bawah 0,7 dalam peubah laten Tata Kelola Perusahaan adalah kepemilikan terkonsentrasi $(0,202)$ dan ukuran dewan komisaris $(0,429)$. Sehingga untuk peubah laten Tata Kelola Perusahaan, indikator kepemilikan terkonsentrasi dan ukuran dewan komisaris harus dikeluarkan dari model. Kepemilikan terkonsentrasi dan dewan komisaris memiliki fungsi yang sama yaitu mengawasi manajerial perusahaan dalam melakukan kegiatan operasional. Perbedaan antara kepemilikan terkonsentrasi dan dewan komisaris adalah kepemilikan terkonsentrasi berasal dari eksternal perusahaan, sedangkan dewan komisaris berasal dari internal perusahaan. Semakin besar kepemilikan saham dari suatu pihak, maka akan meningkatkan pengawasan dan pengendalian dari pihak tersebut. Berdasarkan hal tersebut, maka seharusnya indikator kepemilikan terkonsentrasi dan dewan komisaris dapat merefleksikan peubah laten Tata Kelola Perusahaan. Telah ada peraturan mengenai proporsi minimal dari proporsi dewan komisaris independen sehingga setiap perusahaan yang tercatat harus memiliki proporsi minimal tersebut. Sebagian besar (93\%) perusahaan yang masuk ke dalam indeks LQ45 periode Agustus 2016 sampai Januari 2017 telah memiliki proporsi dewan komisaris independen di atas minimal.

Pada peubah laten Kinerja Saham terlihat bahwa indikator NPM memiliki nilai yang paling rendah $(0,295)$ sehingga harus dikeluarkan dan indikator yang menunjukkan nilai loading factor di atas 0,7 adalah ROA dengan nilai 0,946 dan ROE dengan nilai 0,963. Indikator ROA dan ROE valid dalam mencerminkan peubah laten Kinerja Keuangan. ROA adalah kemampuan perusahaan dalam menghasilkan laba dari aset yang dimiliki, sedangkan ROE adalah kemampuan perusahaan dalam menghasilkan laba dari modal yang dimiliki. Perusahaan yang memiliki tingkat pengembalian yang tinggi terhadap aset dan modal mencerminkan kinerja keuangan yang baik. Indikator ROA dan ROE mampu menggambarkan kinerja keuangan. Investor sangat mempertimbangkan ROA dan ROE perusahaan dalam pengambilan keputusan berinvestasi pada sebuah perusahaan. Sehingga, perusahaan harus mampu meningkatkan kinerja finansial pada indikator tersebut.

Pada peubah laten Kinerja Saham, indikator yang dikeluarkan adalah EPS dengan nilai 0,402. Hal tersebut menyebabkan indikator PBV menjadi indikator satu-satunya dan memiliki nilai loading factor $(1,000)$ di atas 0,7 untuk peubah laten Kinerja Saham. Indikator PBV valid dalam mencerminkan peubah laten Kinerja Saham. Kinerja Saham dapat dilihat dari return saham dan PBV dapat memprediksi tingkat return saham. Semakin tinggi nilai PBV maka investor memiliki kepercayaan yang tinggi terhadap perusahaan untuk memberikan return saham. Indikator PBV merefleksikan peubah kinerja saham, PBV menunjukkan perbandingan antara harga saham dengan nilai bukunya. Jika nilai PBV rendah, maka harganya sahamnya murah. 
Pengukuran terhadap internal consistency atau construct reliability dengan melihat nilai composite reliability dan cronbach's alpha. Composite reliability mengasumsikan kesamaan boot dari setiap indikator sehingga composite reliability akan mengukur reliabilitas dengan lebih baik jika dibandingkan dengan cronbach's alpha. Cronbach's alpha cenderung menaksir reliabilitas konstruk lebih rendah (Yamin dan Kurniawan 2009). Akan tetapi, interpretasi composite reliability sama dengan interpretasi cronbach's alpha dengan nilai batas minimal adalah 0,7. Jika variabel memiliki nilai di bawah 0,7 maka variabel tersebut terindikasi tidak memiliki konsistensi antara indikator dengan peubah latennya.

Tabel 3 Nilai internal consistency

\begin{tabular}{lccc}
\hline & Composite Reliability & Cronbach's Alpha & AVE \\
\hline Tata Kelola & 0,884 & 0,748 & 0,792 \\
Kinerja Keuangan & 0,953 & 0,903 & 0,911 \\
Kinerja Saham & 1,000 & 1,000 & 1,000 \\
\hline
\end{tabular}

Hasil pengolahan data penelitian menunjukkan bahwa nilai composite reliability dan cronbach's alpha telah memenuhi nilai batas yang ditetapkan. Menurut Yamin dan Kurniawan (2009), jika composite reliability dan cronbach's alpha bernilai di atas 0,8 maka indikator tersebut sangat merefleksikan peubah latennya. Berdasarkan Tabel di atas, maka terlihat bahwa sebagian besar indikator penelitian sangat merefleksikan masingmasing peubah latennya.

Pengukuran selanjutnya adalah melihat convergent validity dengan melihat nilai average variance extracted (AVE) yang menggambarkan besarnya varian atau keberagaman variabel manifest yang dapat dikandung oleh peubah laten. Nilai minimal AVE adalah 0,5 yang berarti bahwa peubah laten harus dapat menjelaskan rata-rata lebih dari setengah varian daripada indikator-indikatornya. Berdasarkan Tabel di atas terlihat bahwa semua peubah laten memiliki nilai AVE di atas nilai minimal $(0,5)$. Semakin besar varian indikator yang dimiliki oleh peubah laten maka semakin besar representasi indikator terhadap peubah latennya. Nilai sempurna $(1,000)$ didapatkan peubah laten Kinerja Saham karena peubah laten tersebut hanya mempunyai satu indikator sebagai variabel manifesnya.

Pengukuran selanjutnya adalah discriminant validity yang berfungsi untuk membandingkan korelasi antara indikator dengan peubah latennya dan peubah laten lainnya. Cara untuk mengetahui apakah konstruk memiliki diskriminan yang memadai adalah dengan membandingkan nilai loading pada konstruk yang dituju harus lebih besar jika dibandingkan dengan nilai loading pada konstruk lainnya. Pada model reflektif, pengukuran discriminant validity dilakukan dengan melihat nilai cross loading.

Tabel 4 Nilai cross loading

\begin{tabular}{cccc}
\hline & Tata Kelola & Kinerja Keuangan & Kinerja Saham \\
\hline Komisaris Independen & $\mathbf{0 , 8 4 2}$ & 0,099 & 0,184 \\
Proporsi Dewan Komisaris Independen & $\mathbf{0 , 9 3 6}$ & 0,141 & 0,287 \\
ROA & 0,093 & $\mathbf{0 , 9 4 6}$ & 0,767 \\
ROE & 0,165 & $\mathbf{0 , 9 6 3}$ & 0,911 \\
PBV & 0,274 & 0,885 & $\mathbf{1 , 0 0 0}$ \\
\hline
\end{tabular}

Berdasarkan Tabel di atas dapat dilihat bahwa korelasi masing-masing indikator dengan peubah latennya memiliki nilai yang lebih tinggi jika dibandingkan dengan korelasi indikator dengan peubah laten lainnya. Ringkasan mengenai standar penelitian dan nilai yang diperoleh variabel akan disampaikan pada Tabel 5 . 
Tabel 5 Kriteria nilai standar dan hasil penilaian model reflektif

\begin{tabular}{|c|c|c|c|c|}
\hline No & Kriteria & Penjelasan & Standar & Hasil Penilaian \\
\hline \multirow[t]{5}{*}{1} & Loading factor & Kekuatan indikator & $\geq 0,7$ & $\mathrm{KI}=0,842$ \\
\hline & & dalam & & $\mathrm{PDKI}=0,936$ \\
\hline & & merefleksikan & & $\mathrm{ROA}=0,946$ \\
\hline & & peubah laten & & $\mathrm{ROE}=0,963$ \\
\hline & & & & $\mathrm{PBV}=1,000$ \\
\hline \multirow[t]{3}{*}{2} & Composite & Konsistensi internal & $>0,7$ & $\mathrm{TK}=0,884$ \\
\hline & Reliability & & & $\mathrm{KK}=0,953$ \\
\hline & & & & $\mathrm{KS}=1,000$ \\
\hline \multirow[t]{3}{*}{3} & Cronbach's & Konsistensi internal & $>0,7$ & $\mathrm{TK}=0,748$ \\
\hline & Alpha & & & $\mathrm{KK}=0,903$ \\
\hline & & & & $\mathrm{KS}=1,000$ \\
\hline \multirow[t]{3}{*}{4} & Average & Validitas konstruk & $>0,5$ & $\mathrm{TK}=0,792$ \\
\hline & variance & & & $\mathrm{KK}=0,911$ \\
\hline & extracted & & & $\mathrm{KS}=1,000$ \\
\hline \multirow[t]{6}{*}{5} & Cross loading & Validitas & Setiap indikator memiliki & Semua indikator pada \\
\hline & & diskriminan & nilai loading factor yang & masing-masing peubah \\
\hline & & & lebih tinggi untuk peubah & laten memiliki nilai loading \\
\hline & & & laten yang diukurnya & factor yang lebih tinggi \\
\hline & & & dibandingkan dengan nilai & dibandingkan dengan \\
\hline & & & untuk peubah laten lainnya. & peubah laten lainnya. \\
\hline
\end{tabular}

Model struktural atau inner model menggambarkan pengaruh antara peubah laten. Model struktural dalam penelitian ini dilakukan terhadap tiga pengaruh, yaitu pengaruh antara peubah laten Tata Kelola Perusahaan (TK) terhadap Kinerja Keuangan (KK), Tata Kelola Perusahaan (TK) terhadap Kinerja Saham (KS), dan Kinerja Keuangan (KK) terhadap Kinerja Saham (KS). Evaluasi inner model dilakukan dengan melihat path coefficient bootstrapping dan nilai $R$-square $\left(\mathrm{R}^{2}\right)$.

Tabel 6 Nilai path coefficient bootstrapping

\begin{tabular}{lccccc}
\hline & Original Sample (O) & Sample Mean $(\mathrm{M})$ & Standar Deviation & T Statistics & P Value \\
\hline $\mathrm{TK} \rightarrow \mathrm{KK}$ & 0,139 & 0,131 & 0,235 & 0,590 & 0,556 \\
$\mathrm{TK} \rightarrow \mathrm{KS}$ & 0,155 & 0,090 & 0,103 & 1,497 & 0,135 \\
$\mathrm{KK} \rightarrow \mathrm{KS}$ & 0,864 & 0,864 & 0,070 & 12,279 & 0,000 \\
\hline
\end{tabular}

Pengukuran path cofficient berguna untuk menggambarkan pengaruh antar peubah laten. Penelitian ini menggunakan nilai signifikansi sebesar 0,05 sehingga didapatkan nilai t-tabel sebesar 1,96 dan hipotesis diterima jika |t-hitung| >|t-tabel|. Sedangkan untuk melihat pengaruh antar variabel dapat dilihat melalui nilai koefisien jalur (original sample) dan tanda positif atau negatif pada nilai tersebut. Jika nilai koefisien jalur bertanda positif maka setiap peningkatan atau penurunan variabel eksogen akan meningkatkan atau menurunkan nilai variabel endogen (searah). Jika nilai koefisien jalur bertanda negatif, maka setiap peningkatan variabel eksogen akan menurunkan variabel endogen dan begitupun sebaliknya.

Berdasarkan Tabel 6 dapat dikatakan bahwa penerapan Tata Kelola Perusahaan tidak berpengaruh terhadap Kinerja Keuangan perusahaan sampel. Hal ini terlihat dari nilai |thitung| 0,590 yang lebih kecil daripada |t-tabel| $(1,96)$, sehingga $\mathrm{H}_{1}$ ditolak. Penerapan Tata Kelola Perusahaan direfleksikan dengan jumlah komisaris independen dan proporsi dewan komisaris independen. Sedangkan Kinerja Keuangan direfleksikan dengan nilai ROA dan ROE yang didapatkan oleh perusahaan. Maka dapat disimpulkan bahwa banyaknya jumlah dewan komisaris dan proporsi dewan komisaris independen tidak mempengaruhi Kinerja 
Keuangan perusahaan. Hasil ini bertolak belakang dengan teori yang ada, yang menyatakan bahwa penerapan Tata Kelola Perusahaan dapat meningkatkan kinerja keuangan. Mihaela (2009) dalam Caesari (2015) mengemukakan bahwa elemen kunci untuk meningkatkan efisiensi kinerja adalah penerapan Tata kelola Perusahaan. Penerapan Tata Kelola Perusahaan dapat menciptakan pengawasan optimal dalam penggunaan sumber daya yang dimiliki perusahaan secara lebih efektif. Penerapan Tata Kelola Perusahaan juga memiliki peranan internal di dalam manajemen perusahaan, penerapan Tata Kelola Perusahaan mewajibkan perusahaan untuk menginformasikan kepada pemegang saham mengenai kegiatan dan kondisi secara real sehingga pemegang saham dapat mengambil keputusan secara akurat. Mihaela (2009) dalam Caesari (2015) menekankan bahwa perusahaan menerapkan budaya transparansi dan model efektif dari Tata Kelola Perusahaan akan menghasilkan kinerja yang lebih baik. Adanya perbedaan yang ditunjukkan oleh hasil penelitian diduga disebabkan oleh indikator yang digunakan dalam penelitian. Pada penelitian ini, Tata Kelola Perusahaan hanya memperhitungkan jumlah komisaris independen dan proporsi dewan komisaris independen yang dilihat dari segi kuantitatif saja. Penilaian kualitatif dari kedua indikator tersebut tidak diteliti dikarenakan adanya keterbatasan penelitian. Penilaian kualitatif komisaris independen mempertimbangkan aspek dari setiap individu komisaris independen, seperti latar belakang, kemampuan, kompetensi, pengalaman, profesionalisme, integritas, dan indikator kualitatif lainnya.

Hasil penelitian mengungkapkan bahwa penerapan Tata Kelola Perusahaan tidak berpengaruh terhadap Kinerja Saham perusahaan sampel. Hal ini terlihat dari nilai $\mid t-$ hitung| 1,497 yang lebih kecil daripada |t-tabel| $(1,96)$, sehingga $\mathrm{H}_{2}$ ditolak. Penerapan Tata Kelola Perusahaan direfleksikan dengan jumlah komisaris independen dan proporsi dewan komisaris independen. Sedangkan Kinerja Saham direfleksikan dengan nilai PBV yang didapatkan oleh perusahaan. Maka dapat disimpulkan bahwa banyaknya jumlah dewan komisaris dan proporsi dewan komisaris independen tidak mempengaruhi Kinerja Saham perusahaan yang direfleksikan dengan nilai PBV.

Hasil penelitian mengungkapkan bahwa Kinerja Keuangan berpengaruh nyata terhadap Kinerja Saham perusahaan sampel. Hal ini terlihat dari nilai |t-hitung| 12,279 yang lebih besar daripada |t-tabel| $(1,96)$, sehingga $\mathrm{H}_{3}$ diterima. Nilai koefisien jalur 0,864 bertanda positif sehingga dapat dikatakan bahwa Kinerja Keuangan yang diwakili oleh indikator ROA dan ROE berpengaruh positif terhadap Kinerja Saham perusahaan sampel yang diwakili indikator PBV. Hal ini sejalan dengan penelitian yang dilakukan oleh Fauziah (2016) yang menyatakan bahwa kinerja finansial memiliki pengaruh positif signifikan terhadap kinerja saham.

Evaluasi selanjutnya adalah melihat nilai $R$-square $\left(\mathrm{R}^{2}\right)$, nilai $R$-square $\left(\mathrm{R}^{2}\right)$ menunjukkan seberapa besar keragaman peubah endogen yang dapat dijelaskan oleh peubah eksogen. Peubah endogen dalam penelitian ini adalah Kinerja Keuangan dan Kinerja Saham. Chin (1998) dalam Yamin dan Kurniawan (2009) mengelompokkan nilai $\mathrm{R}^{2}$ menjadi 3 kategori, yaitu substansial $(0,67)$, moderat $(0,33)$ dan lemah $(0,19)$. Berdasarkan hasil penelitian didapatkan nilai $R$-square untuk peubah laten Kinerja Keuangan sebesar 0,019. Hal tersebut berarti bahwa peubah eksogen Tata Kelola Perusahaan secara simultan mampu menjelaskan keragaman peubah endogen Kinerja Keuangan sebesar 1,9 persen dan sisanya sebesar 98,1 persen dijelaskan oleh peubah lain yang tidak diteliti dalam penelitian ini. Hal ini berarti masih banyak variabel lainnya yang dapat mempengaruhi Kinerja Keuangan. Sedangkan nilai $R$-square untuk peubah laten Kinerja Saham adalah 0,807 yang berarti bahwa peubah eksogen Tata Kelola Perusahaan secara simultan mampu menjelaskan keragaman peubah endogen Kinerja Saham sebesar 
80,7 persen dan sisanya sebesar 19,3 persen dijelaskan oleh peubah lain yang tidak diteliti dalam penelitian ini. Tabel di bawah ini menyajikan nilai standar dan nilai yang didapatkan pada penelitian ini.

Tabel 7 Kriteria nilai standar dan hasil penilaian model struktural

\begin{tabular}{|c|c|c|c|}
\hline Kriteria & Penjelasan & Standar & Hasil penilaian \\
\hline $\begin{array}{l}\mathrm{R}^{2} \text { dari peubah } \\
\text { laten endogen }\end{array}$ & $\begin{array}{l}\text { Variabilitas konstruk } \\
\text { endogen yang dapat } \\
\text { dijelaskan oleh variabilitas } \\
\text { konstruk eksogen }\end{array}$ & $\begin{array}{l}\text { Chin (1998) mengelompokkan } \\
\text { nilai } \mathrm{R}^{2} \text { menjadi } 3 \text { kategori, } \\
\text { substansial }(0,67) \text {, moderat } \\
(0,33) \text { dan lemah }(0,19)\end{array}$ & $\begin{array}{l}\mathrm{R}^{2} \text { Kinerja Keuangan }= \\
0,019 \text { (lemah) } \\
\mathrm{R}^{2} \text { Kinerja Saham }= \\
0,807 \text { (substansial) }\end{array}$ \\
\hline $\begin{array}{l}\text { Estimasi } \\
\text { koefisien path }\end{array}$ & $\begin{array}{l}\text { Evaluasi terhadap nilai } \\
\text { koefisien terdiri atas } \\
\text { evaluasi besarnya nilai } \\
\text { original sample dan } \\
\text { pengaruh nyata melalui } \\
\text { bootstrap }\end{array}$ & $\begin{array}{l}\text { Pengaruh nyata jika, } \\
\text { t statistik > t-tabel. } \\
\text { Pada alpha } 5 \text { persen, nilai } \\
\text { t-tabel adalah } 1,96 \text { dan } \\
\text { p value < alpha } 5 \text { persen }\end{array}$ & $\begin{array}{l}\text { Nilai t statistika }: \\
\mathrm{TK} \rightarrow \mathrm{KK}=0,590 \\
\mathrm{TK} \rightarrow \mathrm{KS}=1,497 \\
\mathrm{KK} \rightarrow \mathrm{KS}=12,279 \\
\text { Nilai koefisien }: \\
\mathrm{TK} \rightarrow \mathrm{KK}=0,139 \\
\mathrm{TK} \rightarrow \mathrm{KS}=0,155 \\
\mathrm{KK} \rightarrow \mathrm{KS}=0,864\end{array}$ \\
\hline
\end{tabular}

Hipotesis penelitian yang tidak sesuai dengan teori yang ada disebabkan oleh keterbatasan penelitian atau limitasi penelitian. Keterbatasan penelitian ini di antaranya adalah kinerja perusahaan yang relatif baik karena telah masuk ke dalam indeks LQ45 periode Agustus 2016 - Januari 2017, penelitian hanya menggunakan data sekunder yang menekankan kepada data kuantitatif. Keterbatasan lainnya adalah perusahaan berasal dari sektor yang berbeda, pengambilan data hanya dilakukan pada satu tahun tertentu dan tidak mempertimbangkan dimensi jangka panjang. Landasan teori yang digunakan dalam penelitian ini masih bersifat tentatif dan tidak adanya pendefinisian yang pasti mengenai variabel penelitian. Variabel Tata Kelola Perusahaan belum memiliki instrument pengukuran yang baku seperti variabel Kinerja Keuangan dan Kinerja Saham.

\section{Implikasi Manajerial}

Hasil penelitian menunjukkan bahwa penerapan Tata Kelola Perusahaan tidak berpengaruh nyata dan bersifat positif terhadap Kinerja Keuangan maupun Kinerja Saham. Berdasarkan hal tersebut, maka dapat dikatakan bahwa hipotesis pertama dan hipotesis kedua pada penelitian ini tidak terbukti. Hasil tersebut bertolak belakang dengan teori yang ada. Berdasarkan teori yang ada, Kinerja Keuangan dapat ditingkatkan dengan adanya penerapan Tata Kelola Perusahaan yang baik. Berdasarkan analisa dalam penelitian, penerapan Tata Kelola Perusahaan direfleksikan dengan Komisaris Independen dan Proporsi Dewan Komisaris Independen memiliki hubungan positif dengan Kinerja Keuangan. Dapat disimpulkan bahwa semakin tinggi variabel Tata Kelola Perusahaan akan meningkatkan Kinerja Keuangan. Namun, Tata Kelola Perusahaan hanya berkontribusi sebesar 1,9 persen untuk meningkatkan Kinerja Keuangan, sedangkan sisanya dipengaruhi oleh faktor-faktor lain yang tidak diteliti dalam penelitian ini. Penerapan Tata Kelola Perusahaan berkontribusi sebesar 80,7 persen untuk meningkatkan Kinerja Saham, sedangkan sisanya dipengaruhi oleh variabel lain yang tidak diteliti dalam penelitian ini. Kontribusi ini terlihat besar namun tidak signifikan. Hasil hipotesis penelitian ini bertolak belakang dengan teori yang ada, dimana perusahaan yang menerapkan Tata Kelola Perusahaan secara tepat akan memiliki citra positif bagi stakeholder maupun shareholder. Sehingga akan berdampak secara tidak langsung pada peningkatan profitabilitas dan 
permintaan saham. Hal ini berarti bahwa harga saham yang beredar akan mengalami peningkatan juga.

Hasil hipotesis ketiga menyatakan bahwa Kinerja Keuangan yang direfleksikan dengan ROA dan ROE berpengaruh nyata terhadap Kinerja Saham yang direfleksikan dengan PBV. Tujuan perusahaan dalah mendapatkan laba atau keuntungan setinggitingginya, hal ini dapat dicapai jika manajemen perusahaan dapat meningkatkan Kinerja Keuangan perusahaan. Kinerja Keuangan yang baik akan menjadi daya tarik tersendiri bagi investor untuk melakukan investasi di suatu perusahaan. Hal ini akan berdampak kepada naiknya Kinerja Saham. ROA dan ROE merupakan variabel yang harus diperhatikan oleh perusahaan. Pengembalian yang tinggi terhadap modal dan aset akan memberikan gambaran capital gain terhadap investor ketika dilakukan pengambilan keputusan dalam berinvestasi.

Hasil penelitian yang tidak sesuai dengan hipotesis, penelitian terdahulu, maupun teori disebabkan karena adanya keterbatasan penelitian. Keterbatasan penelitian yang ditemukan di antaranya adalah kinerja perusahaan yang relatif baik karena telah masuk ke dalam indeks LQ45 periode Agustus 2016 - Januari 2017, penelitian hanya menggunakan data sekunder yang menekankan kepada data kuantitatif, dan pengambilan data hanya dilakukan pada satu tahun tertentu dan tidak mempertimbangkan dimensi jangka panjang.

\section{SIMPULAN DAN SARAN}

\section{Simpulan}

Penerapan Tata Kelola Perusahaan yang direfleksikan dengan indikator Komisaris Independen dan Proporsi Dewan Komisaris Independen sudah baik. Hal ini ditunjukkan dengan hampir seluruh perusahaan yang terindeks dalam LQ45 Periode Agustus 2016 Januari 2017 telah memenuhi batas minimal proporsi Dewan Komisaris Independen yang telah ditetapkan Bursa Efek Indonesia (BEI) per tanggal 1 Juli 2000. Kinerja Keuangan dan Kinerja Saham yang dicapai perusahaan tergolong baik, terlihat dari nilai-nilai yang digunakan sebagai indikator untuk merefleksikan Kinerja Keuangan dan Kinerja Saham.

Penerapan Tata Kelola Perusahaan tidak berpengaruh terhadap Kinerja Keuangan maupun Kinerja Saham, hal ini bertentangan dengan teori yang ada. Penerapan Tata Kelola Perusahaan seharusnya dapat meningkatkan patuhnya perusahaan terhadap aturan-aturan yang berlaku untuk mencapai tujuan perusahaan. Adanya perbedaan ini diduga disebabkan oleh keterbatasan penelitian yang melihat variabel Tata Kelola Perusahaan hanya dari segi kuantitatif.

Kinerja Keuangan berpengaruh positif signifikan terhadap Kinerja Saham. Semakin baik Kinerja Keuangan yang dilakukan oleh perusahaan, maka Kinerja Saham yang dimiliki oleh perusahaan akan meningkat.

\section{Saran}

Penerapan Tata Kelola Perusahaan harus disesuaikan dengan karakteristik perusahaan dan model penerapan Tata Kelola Perusahaan pada satu perusahaan belum tentu akan mengakibatkan imbas yang sama dengan perusahaan lainnya. Setiap perusahaan memiliki model penerapan Tata Kelola Perusahaan yang berbeda-beda. Perusahaan juga harus mempertimbangkan karakteristik dewan komisaris maupun dewan komisaris independen dalam rangka menerapkan Tata Kelola Perusahaan. Sehingga proporsi dewan komisaris independen yang ada menjadi lebih efektif dan efisien dalam melakukan pengawasan. Perusahaan perlu memperhatikan Kinerja Keuangan perusahaan dalam meningkatkan Kinerja Saham. Kinerja Keuangan yang baik dapat memperlihatkan 
keuntungan yang akan didapatkan oleh pemegang saham, sehingga hal tersebut menjadi daya tarik bagi investor dalam pengambilan keputusan berinvestasi.

Bagi penelitian selanjutnya diharapkan dapat melihat variabel Tata kelola Perusahaan dari segi kualitatif untuk lebih memperdalam variabel Tata Kelola Perusahaan. Selain itu, pertimbangan jangka waktu dalam kurung waktu yang lama memungkinkan peneliti dapat melihat perkembangan penerapan Tata Kelola Perusahaan, Kinerja Keuangan, dan Kinerja Saham perusahaan dengan lebih baik.

\section{DAFTAR PUSTAKA}

[Bursa Efek Indonesia. 2016. IDX LQ45 Periode Agustus 2016 - Januari 2017. [Internet]. [diunduh 2016 Desember 15]. Tersedia pada : http://www.idx.co.id/Portals/0/StaticData/Publication/LQ45/20161010_IDX-LQ45August-2016.pdf.

Cadbury A. 1992. The Financial Aspects of Corporate Governance. The Committee on the Financial Aspects of Corporate Governance and Gee and Co Ltd : London (UK). [Internet]. [diunduh 2016 Desember 15]. Tersedia pada : http://www.ecgi.org/codes/documents/cadbury.pdf.

Caesari, Annisa Putri. 2015. Pengaruh Tata Kelola Perusahaan dan Tanggung Jawab Sosial Perusahaan terhadap Kinerja Keuangan pada Perusahaan Indeks KOMPAS100. [tesis] Institut Pertanian Bogor. Bogor (ID).

Dachlan Usman. 2014. Panduan Lengkap Structural Equation Modeling : Tingkat Dasar Metodologi, Konsepsi, Aplikasi dengan AMOS. Lentera Ilmu : Semarang (ID).

Drobetz W, Schillhofer A, dan Zimmermann H. 2003. Corporate Governance and Expected Stock Returns: Evidence from Germany. Working Paper No.2/03 [Jurnal]. WWZ Department of Finance, University of Basel (CH). [Internet]. [diunduh 2016 Desember 15]. Tersedia pada http://www.econbiz.de/archiv1/2008/59472_expected_stock_returns.pdf

Fahmi I. 2012. Analisis Kinerja Keuangan. Alfabeta : Bandung (ID).

Fauziah, Gusfarini. 2016. Pengaruh pengungkapan corporate social responsibility terhadap nilai perusahaan pada indeks saham LQ45. [tesis] Institut Pertanian Bogor. Bogor (ID).

Ghozali Imam. 2008. Structural Equation Modeling: Metode alternative dengan Partial Least Square (PLS). Badan Penerbit UNDIP : Semarang (ID).

Lestari MI, Sugiharto T. 2007. Kinerja Bank Devisa dan Bank Non Devisa dan FaktorFaktor yang Mempengaruhinya. Proceeding PESAT (Psikologi, Ekonomi, Sastra, Arsitek, dan Sipil). 21-22 Agustus Vol 2. Universitas Gunadarma : Depok (ID).

Subiyanto H. 2009. Intisari Manajemen Keuangan. PT Grasindo : Jakarta (ID).

Subiyantoro, Edi dan Andreani, Fransisca. 2003. Analisis Faktor-Faktor yang Mempengaruhi Harga Saham. Jurnal Manajemen \& Kewirausahaan Vol.5 No.2, September 2003 : 171-180. Jurusan Ekonomi Manajemen Fakultas Ekonomi Universitas Kristen Petra. [Internet]. [diunduh 2016 Desember 15]. Tersedia pada : http://puslit.petra.ac.id/journals/management/.

Sutojo S dan Aldridge EJ. 2008. Good Corporate Governance: Tata Kelola Perusahaan yang Sehat. PT Damar Mulia Pustaka : Jakarta (ID).

Warsono S, Amalia F, Rahajeng DK. 2009. Corporate Governance Concept and Model. Center for Good Corporate Governance (CGCG) Fakultas Ekonomi UGM : Yogyakarta (ID). 
Yamin dan Kurniawan. 2009. Structural Equation Modeling: Belajar lebih mudah teknik analisis data kuesioner dengan Lisrel-PLS. Salemba Infotek : Jakarta (ID). 